\title{
Edward $\mathrm{Gu}$ and Merle Goldman (eds.), Chinese
} Intellectuals Between State and Market

London and New York, Routledge Curzon, 2004, 298 p.

\section{Aurore Merle}

\section{OpenEdition}

\section{Journals}

Electronic version

URL: http://journals.openedition.org/chinaperspectives/471

DOI: 10.4000/chinaperspectives.471

ISSN: 1996-4617

\section{Publisher}

Centre d'étude français sur la Chine contemporaine

Printed version

Date of publication: 1 April 2005

ISSN: 2070-3449

\section{Electronic reference}

Aurore Merle, «Edward Gu and Merle Goldman (eds.), Chinese Intellectuals Between State and Market »,

China Perspectives [Online], 58 | march - april 2005, Online since 29 November 2006, connection on 24 September 2020. URL : http://journals.openedition.org/chinaperspectives/471 ; DOI : https://doi.org/ 10.4000/chinaperspectives.471

This text was automatically generated on 24 September 2020

(c) All rights reserved 


\title{
Edward $\mathrm{Gu}$ and Merle Goldman (eds.), Chinese Intellectuals Between
} State and Market

London and New York, Routledge Curzon, 2004, 298 p.

\author{
Aurore Merle
}

\section{EDITOR'S NOTE}

Translated from the French original by Philip Liddell

1 This collective work, directed by two writers known for their work on China's intellectuals ${ }^{1}$, undertakes to bring together with the classic problem of intellectuals and the state in China a further key notion : the market. Has the introduction of market mechanisms to the Chinese intellectual sphere changed the relationship between intellectuals and the state in the post-Tian'anmen period? Has it been the source of greater autonomy for the intellectuals?

2 To answer these questions, the book is divided into four parts. The first looks at changes in the public intellectual sphere. It tackles subjects as diverse as the unprecedented development of "non-governmental intellectual organisations" (Edward Gu), the influence of the market on China's media output (Yuezhi Zhao), and some intellectual controversies that have appeared on the Internet (Gérémie R Barmé and Gloria Davis). The aim is to measure the extent of the changes affecting the environment within which intellectuals of the 1990s were operating.

3 Secondly, the writers examine the restructuring of links between the Party-state and the intellectuals: why, now that the reforms have allowed some relaxation of the state's patronage of them, do the intellectuals prefer to be part of the establishment and to adopt a co-operative attitude towards the state? Suzanne Ogden suggests that the state is willing to permit-as a safety valve-the expression of some intellectual criticism. She also stresses the ambiguous effects created by the arrival of the market 
and mass culture : ironically, these have increased the intellectuals' dependence on the state. Richard P Suttmeier and Cong $\mathrm{CaO}^{2}$, basing themselves on a survey of 150 Chinese scientists, point to the growing commercialisation of research, the changing nature of bureaucratic intervention within the scientific sphere and, above all, the development of an academic culture endowed with its own criteria for evaluation and selection. Teresa Wright recounts the history of the Democratic Party of China, showing how intellectuals in dissident organisations were increasingly marginalised during the 1990s.

4 The third part is devoted to putting into perspective some ideological alternatives that have structured the intellectual public sphere in recent years : Xu Jilin looks back over twenty years of debate to show that the consensus among intellectuals during the $1980 \mathrm{~s}$ exploded during the 1990s to reveal deep divisions, both intellectual and ideological. Timothy Cheek compares the historical essays published by Deng Tuo at the height of the Maoist period with those of Xu Jilin at the end of the 1990s, to reflect on the changing role of historians as intellectuals engaged with contemporary China. To understand the renewal of the liberal trend at the end of the 1990s, Feng Chongyi recounts the eventful and complex history of liberalism in China. In the fourth part, Baogang He sums up the new roles played by Chinese intellectuals confronted by the challenges of liberalism, social democracy, professionalisation and globalisation.

This book's main contribution is to warn readers against any reductionist or simplistic vision of how China's intellectual sphere is developing. In the tradition of work by Merle Goldman, Timothy Cheek and others ${ }^{3}$, the writers set out to show that the dichotomous categories in which Western writers characterise intellectuals-the dissident intellectual and the establishment intellectual-far from being opposed in the Chinese case can be two facets of the same reality. The writers even suggest that it is the figure of the committed intellectual within the establishment that could become the dominant model for the 1990s.

The perspective is also historical: while the writers concentrate on changes in the postTian'anmen period, they take equal care to show continuities with the preceding period and with history before that. This rigorous approach helps them to avoid the trap of newness and to place conflicts where one might not necessarily expect them: thus, Gérémie R Barmé and Gloria Davis advance the idea that the new forms of intellectual controversy, far from being the result of technological possibilities offered by the Internet, reflect the economic and cultural influence of Hong Kong and Taiwan.

7 Rather than setting in opposition, out of hand, the state as a factor of oppression and the market as one of freedom, the authors favour precise studies to disclose the contradictory and sometimes paradoxical effects of both upon intellectual output. Thus, Yuezhi Zhao shows that, in the Chinese media field, political propaganda and commercial propaganda are not so much opposed as complementary to each other. Richard P Suttmeier and Cong Cao also insist that the challenge facing the scientific community today does not lie in state-market opposition but in the combination of market and state mechanisms with the resources available to this community.

This book offers a subtle, complex and sometimes paradoxical view of the present-day Chinese intellectual community. This is achieved, the authors suggest, by depicting a period of transition strongly marked by uncertainty. However, by insisting mainly on the institutional developments affecting the intellectual sphere, the book gives little substance in the end to the intellectuals themselves or to their choices. Often 
describing the latter as a rational reaction to developments within their environment, the book does not enable us really to understand the revival of debate or the intellectual engagement during the period studied. Moreover, society itself is conspicuously absent from the consideration of this intellectual world in transition. Some articles do raise the question of where Chinese intellectuals stand in relation to the new social stratification; some do mention the close connections between some intellectuals and the new economic elite created by the reforms, or conversely the rift that has opened between intellectuals and ordinary citizens; but the question of links between intellectuals and rest of society is never really addressed. It so happens that the development of the intellectual sphere during the 1990s precisely corresponds to the explosion of social problems in China ; it corresponds also to the emergence and development of social activism-supposed to be a substitute for political activitywhich arises exactly half-way between the state and the market. How do the intellectuals respond to these challenges? What do they think about contemporary Chinese society? Do there exist forms of intellectual engagement oriented towards action on society? Tackling such questions may have added depth to the wide range of thinking within these pages.

\section{ENDNOTES}

1. See Merle Goldman, China's Intellectuals Advise and Dissent, Harvard University Press, 1981 ; Sowing the Seeds of Democracy in China, Political Reforms in the Deng Xiaoping Era, Harvard University Press, 1994 ; "Politically-Engaged Intellectuals in the Nineties", China Quarterly, No. 159, September 1999. See also Edward Gu, "Cultural Intellectuals and the Politics of the Cultural Public Space in Communist China (1979-1989): A Case Study of Three Intellectual Groups", The Journal of Asian Studies, 58, No. 2, May 1999; "Plural Institutionalism and the Emergence of Intellectual Public Spaces in China : A Case Study of Four Intellectual Groups", in Suisheng Zhao (ed.), China and Democracy: The Prospect for a Democratic China, Routledge, 2000.

2. Cong Cao has published the complete results of his survey in a book entitled, China's Scientific Elite, Routledge Curzon, 2004.

3. See Merle Goldman, Timothy Cheek, Carol Lee Hamrin, China's Intellectuals and the State, in Search of a New Relationship, Harvard University Press, 1987 ; Hamrin, Cheek, China's Establishment Intellectuals, M E Sharpe, 1986. 